IZA DP No. 1041

The Public Sector Pay Gap in France, Great Britain and Italy

\author{
Claudio Lucifora \\ Dominique Meurs
}

March 2004 


\title{
The Public Sector Pay Gap in France, Great Britain and Italy
}

\author{
Claudio Lucifora \\ Università Cattolica del Sacro Cuore, \\ ERMES, CHILD and IZA Bonn \\ Dominique Meurs \\ Université Paris 2, ERMES
Discussion Paper No. 1041
March 2004

\author{
IZA \\ P.O. Box 7240 \\ 53072 Bonn \\ Germany \\ Phone: +49-228-3894-0 \\ Fax: +49-228-3894-180 \\ Email: iza@iza.org
}

\begin{abstract}
Any opinions expressed here are those of the author(s) and not those of the institute. Research disseminated by IZA may include views on policy, but the institute itself takes no institutional policy positions.

The Institute for the Study of Labor (IZA) in Bonn is a local and virtual international research center and a place of communication between science, politics and business. IZA is an independent nonprofit company supported by Deutsche Post World Net. The center is associated with the University of Bonn and offers a stimulating research environment through its research networks, research support, and visitors and doctoral programs. IZA engages in (i) original and internationally competitive research in all fields of labor economics, (ii) development of policy concepts, and (iii) dissemination of research results and concepts to the interested public.
\end{abstract}

IZA Discussion Papers often represent preliminary work and are circulated to encourage discussion. Citation of such a paper should account for its provisional character. A revised version may be available on the IZA website (www.iza.org) or directly from the author. 


\section{ABSTRACT \\ The Public Sector Pay Gap in France, Great Britain and Italy*}

We investigate public-private pay determination using French, British and Italian microdata. While traditional methods focus on parametric methods to estimate the public sector pay gap, in this paper, we use both non-parametric (kernel) and quantile regression methods to analyse the distribution of wages across sectors. We show that the public-private (hourly) wage differential is sensitive to the choice of quantile and that the pattern of premia varies with both gender and skill. In all countries the public sector is found to pay more low skilled workers with respect to the private sector, whilst the reverse is true for high skilled workers. The effects are more pronounced for females.

JEL Classification: J31, J45, C14

Keywords: wage differentials, public sector, quantile regression

Corresponding author:

Claudio Lucifora

Università Cattolica del Sacro Cuore

1, Largo Gemelli

20123 Milano

Italy

Email: claudio.lucifora@unicatt.it

\footnotetext{
* This paper is part of the PIEP (Pay Inequality and Economic Performance) Project financed by the EU under the $V$ framework (contract N.HPSE-CT-1999-00040). We are grateful to Simona Comi, Carlo Dell'Aringa, Paolo Ghinetti, Robert Elliott, PIEP members and to the participants at seminars in Università Cattolica-Milan, Université Paris2, Paris and XV EALE Conference held in Seville, for useful comments. We grateful to IRESCO-CNRS (France), Bank of Italy (Italy), UK Data Archive (Great Britain) for supplying national data set. Usual disclaimer applies.
} 


\section{Introduction}

In many OECD countries public sector employment accounts for a significant share of total employment and public sector expenditures, as well as playing an important role in economic performance. The institutional setting governing human resources management and pay determination, as well as the goods and services (respectively) offered, however, can differ significantly between the public and private sector. In this context, relative pay also shows substantial heterogeneity by gender and skill levels between the two sectors, whilst both sectors compete on the labour market. Among other things, these features have important implications for the functioning of the labour market in terms of workers-job queues, 'wait' unemployment, as well as adverse effects in recruitment, retention and incentive policies. Empirical evidence on the public sector pay gap suggests, even after controlling for observable characteristics, a positive wage differential for public sector workers and a higher premia for women as compared to men; also, pay dispersion is usually found to be lower in the public sector with respect to the private sector. Given existing differences in the distribution of wages across public and private sectors, public sector pay gap estimates proved, in general, rather sensitive to sample choice, empirical specification and the group of worker selected (Gregory and Borland, 1999).

In this paper, we investigate public-private pay determination comparing different institutional settings and public sector pay formation, using French, British and Italian microdata. Our findings contribute to the existing literature in several ways. First, by focussing on different countries we exploit institutional differences to gain insights on the process of pay formation. Second, while traditional methods focus on a parametric approach to estimate the public sector pay gap, we use both non-parametric and quantile regression methods to analyse the distribution of wages across sectors. We show that the public-private (hourly) wage differential is sensitive to the choice of quantile and that the pattern of premia varies with both gender and skill. We argue that the decomposition of predicted wage gaps at diverse quantiles provides a more accurate set of measures for the size of the part of the wage gap that is attributed to different returns to skills between the public and private sector. In all countries the public (private) sector is found to pay more (less) low skill workers with respect to the private (public) sector, whilst the reverse is true for high skill workers. The effects are more pronounced for females. Finally, when the wage differential is decomposed by quantile, using an Oaxaca-Ransom type decomposition, we show that a significant portion is explained by observed characteristics (over 60 percent on average) and is increasing over the wage 
distribution. Symmetrically, the unexplained part due to the wage differential between public and private sector decreases and becomes close to zero at the highest quantiles, suggesting that differences in unobserved characteristics are more important at lower quantiles.

The paper is organised as follows. We start by comparing the institutional system and pay setting in each country. Next, in section 3, we describe the data and present some descriptive statistics. Section 4 discusses the empirical strategy and compares results from the standard OLS approach to quantile regression methods. In section 5 we investigate further the differences in the public sector pay gap across countries. Conclusions follow.

\section{Institutional Differences in Public Sector Pay}

The set of rules governing terms and conditions of employment and pay are quite different across the public and private sectors, in all countries. Despite the substantial changes introduced in recent decades to increase both competition and efficiency of the public sector, still significant differences exist between the two sectors. The latter range from the criteria adopted, in each sector, to select, recruit and promote workers, to adjust wage levels, as well as in terms of wage profiles, career advancement and the role played by collective bargaining and trade unions. In Italy and France public servants are still generally recruited through open, competitive examinations - for which a given level of education is required - and, once hired, enjoy life-time contracts in which seniority plays a major role. In general, public servants in the above countries cannot be discharged, except for misconduct, and the statutory terms apply regardless of whether the individual is employed at the national, regional of local authority level. Conversely, in Great Britain the process of decentralisation has determined, on the one hand, a significant variation both in recruitment criteria and pay levels of civil servants across different Departments within the public sector, whilst, on the other, a number of services have been progressively contracted out.

In the private sector, as opposed to the public, the degree of regulation is generally much lower in all countries. Italy and France, however, are still characterised by quite strict job protection measures, extensive coverage of collective agreements and a rather centralised system of pay determination, whilst in Great Britain pay determination is highly decentralised, unions are weaker and job protection is fairly low (Oecd, 2000). As it might be expected, pay inequality is greater and low pay employment is larger in Great Britain as compared to both France and Italy (Oecd, 1996; Lucifora, 2000).

In this context, differences in the rules governing public and private sector employment may well have a role in determining relative pay differentials within each 
country. However, also differences across countries in the institutional setting - i.e. pay regulation, collective bargaining coverage and extension, private sector comparability provisions, etc. -- are likely to affect the structure and magnitude of the public sector pay gap. In France collective bargaining, in the private sector, establishes industry minima for wages and employment conditions, whilst, in the public sector, unions also take part in national wage negotiations but the outcome is not legally binding for the government ${ }^{1}$. In practice civil servants are not allowed to engage in collective bargaining and their pay is set by statute with the same pay scales applying to all public sector workers (Guillotin and Meurs, 1999). In Italy, collective bargaining in the private sector takes place at the industry level, while in the public sector wage levels and wage adjustments are all decided at the central level (Dell'Aringa and Della Rocca, 1996) ${ }^{2}$. Conversely, in Great Britain, civil servants are covered by a variety of different arrangements, which include: Review Bodies, index linking, decentralised as well as centralised collective bargaining. In recent years, policies such as contracting-out and competitive tendering have also contributed to a progressive 'privatisation' of pay setting procedures (Bender and Elliott, 1999). Thus, whilst in Great Britain private sector pay is used as a reference point for pay determination in the public service (at least in some part of it), France and Italy lack any application of this comparability principle and the reference is, in general, given by cost of living and public budget conditions. Minimum wage legislation also has different applications in these countries, being relevant in Great Britain and France but absent in Italy. The different set of institutional rules that govern pay determination in the public sector, in the three countries considered, provides an interesting source of variation for assessing whether collective bargaining practices, private sector pay comparability standards, as well as other factors, have an impact on the publicprivate wage differential.

\subsection{Public-Private Pay: some stylised facts}

Comparing (gross) pay levels across public and private sectors is not without problems. The more the public sector undertakes activities that are not found in the private sector and the lower is substitutability in the goods and services provided by each sector, the more difficult comparability is and the higher is the scope for pay differences existing across

\footnotetext{
${ }^{1}$ Collective bargaining was extended as a result of the "Auroux law" in 1982.

2 Public sector pay negotiations cover each of the eight functional sub-sectors defined as a result of the 1993 civil service reform in which an independent agency (Agenzia per la reppresentanza sindacale nel pubblico impiego - ARAN) has been invested of negotiating for public sector employees. The police and armed forces, university professors and other academic staff, judges and prosecutors, as well as senior civil servants are
} 
sector. Moreover, since the vast majority of doctors, nurses, teachers, policemen and judges are employed in the public sector, while insurance salesmen, assembly workers, stock and bond dealers are exclusive of private sector, average qualification and job contents are likely to differ and hence comparison of (unconditional) pay levels across sector can prove misleading. With these caveats in mind, if we look the raw average difference in pay between public and private sector, we find that these are quite different and equal to 11.5, 28.5 and 16.1 percent, respectively for France, Italy and Great Britain. However, if we account for the existing heterogeneity in the characteristics of the workforce in the two sectors by conditioning on a set of personal and job characteristics pay differential are much lower than what suggested from raw data: namely between 5 and 6 percent in all countries. Apart from average differences, one common feature shared by most countries is that minimum rates of pay for least skilled workers are higher in the public as opposed to the private sector. This is the result of a number of features that impact differently on the private and the public sector. A wider union presence and a more effective use of union power -- which protect low paid workers --; as well as 'fair' rates of pay offered by the State (as "good employer") to the least skilled, all tend to reduce wage dispersion in the lower part of the distribution in the public sector as compared to the private (Bender and Elliott 1999). Conversely, the rates paid to the most senior public servants have often reported to be substantially lower than those paid to individuals with comparable skills and responsibility in the private sector: public opposition to high rates of pay for public servants seems to account for this feature (Katz and Kreuger, 1991; Lucifora, 1999). Whilst, the combined effects of these features is conducive to a much flatter public sector wage structure than the private sector (as shown in figure 1); an additional effect works through the larger proportion of low paid individuals in the private sector of the economy, where both monopsony and discrimination effects have been documented to be larger (Bazen, Gregory and Salverda, 1998). The economic consequences of such an imbalance, assuming the private sector as the reference sector, are that the public sector pays more than the opportunity wage for unskilled and low skilled labour. On the contrary, under the hypothesis that labour market failures are less relevant for skilled individuals in the private sector, the rates paid to high skilled workers in the public sector appear to be less than what would be needed to attract, retain and motivate such workers. Clearly, the underlying distortions in relative pay, in both sides of the distribution, makes human resource management and recruitments decisions particularly difficult.

excluded from these negotiations. 
Figure 1 - Pay profiles by skill: Public and private sectors

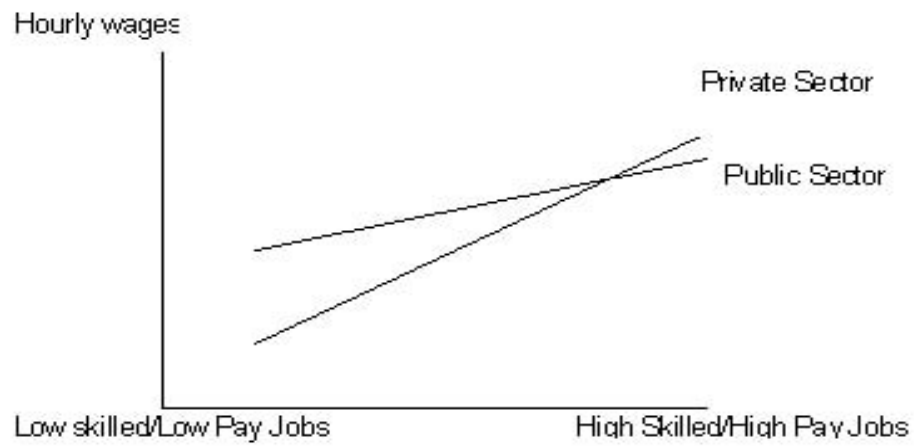

There are of course several features that are missing from a simple wage comparison which might be relevant. For example, other dimensions of the work package and the work environment such as job security, risk and injury at work, may play a role (Hamermesh and Wolfe, 1990; Sandy and Elliott, 1996). Also, workers might be heterogeneous across sectors with respect to some unmeasured characteristics in a non random way, such as preference for public sector work, desire to be a civil servant, or work in the non-profit sector, and self-select themselves according those features. In this paper, while acknowledging the caveats that the features discussed above may imply, we restrict attention to the public sector pay gap as measured by hourly wages and focus on pay differentials between the public and the private sector that emerge along the entire wage distribution. The next section briefly reviews the empirical evidence and discusses the main results from previous studies.

\subsection{Previous Studies}

The analysis of public sector labour market has not attracted much attention among economists in European countries, and the number of studies which have attempted to compare job and pay conditions across sectors is rather limited. In general, most studies that have investigated relative wages across sectors used a standard wage equation approach where the public-private differential is estimated by means of a dummy variable identifying the public sector or by estimating separate equations and computing the implied wage differentials using the Oaxaca-Ransom methodology. Some studies have also attempted to model the choice of the sector jointly with wage determination and then correct the estimation of the public-private differential ${ }^{3}$. In general, results from the above studies show a great deal

\footnotetext{
${ }^{3}$ A number of studies estimated a sectoral choice equation which is then used to correct the coefficients in the
} 
of variation in the estimated differentials depending on the sample selected, the definition of the public sector, the specification chosen and the identification strategy used. These features, however, complicate considerably comparisons across countries.

Here, we focus attention on the main results of the empirical studies which have investigated public and private sectors wage differentials in Great Britain, Italy and France. The general finding in Great Britain is that, on average, civil servants earn more than comparable workers in the private sector (Rees and Shah, 1995; Disney and Gosling, 1998, 2003; Blackaby, Murphy and O'Leary, 1999; Bender and Elliott, 1999). The average differential controlling for standard human capital variables is close to 5 percent, although it is much higher for females (15-18 percent) as compared to men (2-5 percent); while approximately half of the raw differential is explained by differences in observed characteristics. Evidence for Italy also suggests a relatively large raw (positive) differential between the public and the private sector (Cannari et al., 1989; Brunello and Dustmann, 1997; Bardasi, 1996; Lucifora, 1999; Comi, Ghinetti and Lucifora, 2002). After conditioning on a set of variables, the differential results moderate for men (10 percent) and higher for females (18-20 percent). The largest portion of the wage gap, however, can be attributed to differences in the observed characteristics of workers (90 percent), whilst only small differences in returns exist between the sectors. Finally, quite surprisingly, only a few studies have investigated the issue of public sector pay differentials in France (Insee, 1996; Fournier, 2001). These studies suggest that in the public sector there is a positive (negative) premium for low (high) skilled and that being a female also grants a positive premium.

Results from standard decomposition methods, in all the countries considered, point to similar results: namely a rather small wage differential - once differences in characteristics are controlled for - for adult males, while a more significant positive differential is detected when female are considered.

Given the differences in the distribution and dispersion of pay between the sectors, the standard approach based on the analysis of the conditional mean of the distribution has been criticized in a number of studies. For the US, Poterba and Rueben (1994) report evidence suggesting that the wage distribution for the public sector is much less dispersed and propose alternative methods to analyse pay differentials based on quantile regression. Mueller (1998) provides a decomposition of wage differentials at several quantiles of the densities, applied to workers in the public and private sectors in Canada. In the UK, Blackaby, Murphy and

wage equations. Notable examples of such an approach are: Godderis, (1988) and Hartog and Osterbeek, (1993). Few studies also use fixed effect estimators to analyse public sector pay differentials, exemples are Disney and Gosling (1998 and 2003). However, both approaches are not without problems (Nawata, 1996; and Manski, 1993 and 1995). 
O'Leary (1999) and Disney and Gosling (1998) show that the public sector pay gap vary along the distribution, being higher for the lowest deciles with respect to the top deciles. Melly (2002), in Germany, also finds that the differential decreases monotonically as one moves up the wage distribution.

\section{Data and descriptive statistics}

This study uses microdata for Great Britain, France and Italy, for 1998. Data used is drawn from National Surveys, respectively: British data from the Labour Force Survey (GBLS), Italian data from the Bank of Italy's Survey of Household Income and Wealth (SHIW) and French data from Enquéte Emploi (FREE). Each National Survey provides information on standard human capital variables (i.e. education, gender, marital status, age, work experience), occupation, region of residence, gross earnings, hours worked, and a public sector identifier ${ }^{4}$. We restrict our samples to non-agricultural employees aged from 15 to 70. In table 1 , we report the main features of the National data sets, and compare public and private sector workers. Descriptive statistics show that, on average, civil servants are older, more educated and work shorter hours in all countries. The public sector employs more females, more part timers and a larger share of white collar workers. Furthermore, when comparing hourly wages, public sector employees - both males and females --are shown to earn higher wages 5 .

\footnotetext{
4 The definition retained for the public sector is the same in all countries. It includes Central and Local Administrations, Health and Education and excludes firms, financed by the State, but operating on the market. 5 In 1998 parities for the Euro were fixed within the European Monetary Union (EMU), hence this is what we used for France and Italy. As far as Great Britain is concerned, we used the average exchange rate for 1998 (European Parliament, 1998).
} 
Table 1. Sample Descriptive Statistics

\begin{tabular}{|c|c|c|c|c|c|c|}
\hline & \multicolumn{2}{|c|}{ France } & \multicolumn{2}{|c|}{ Italy } & \multicolumn{2}{|c|}{ Great-Britain } \\
\hline & Private & Public & Private & Public & Private & Public \\
\hline \multicolumn{7}{|l|}{ Personal Characteristics } \\
\hline age & 38,8 & 41,4 & 37,2 & 42,9 & 38,2 & 41,7 \\
\hline Education (years) & 13,0 & 14,1 & 10,1 & 12,5 & 12,0 & 13,0 \\
\hline Females & 0,432 & 0,601 & 0,360 & 0,549 & 0,452 & 0,644 \\
\hline Marry & 0,750 & 0,761 & 0,607 & 0,767 & 0,586 & 0,661 \\
\hline \multicolumn{7}{|l|}{$\underline{\text { Job attributes }}$} \\
\hline workers & 0,395 & 0,113 & 0,611 & 0,144 & 0,505 & 0,342 \\
\hline clerks & 0,304 & 0,439 & 0,315 & 0,475 & 0,183 & 0,169 \\
\hline intermediate & 0,251 & 0,394 & 0,054 & 0,344 & 0,142 & 0,393 \\
\hline managers & 0,050 & 0,054 & 0,020 & 0,035 & 0,170 & 0,096 \\
\hline part time & 0,162 & 0,212 & 0,080 & 0,055 & 0,217 & 0,312 \\
\hline \multicolumn{7}{|l|}{$\underline{\text { Wages }}$} \\
\hline \multicolumn{7}{|l|}{ Males } \\
\hline Hours & 39,77 & 38,83 & 41,64 & 37,22 & 39,77 & 37,76 \\
\hline Log hourly wage $(€)$ & 2,123 & 2,238 & 2,072 & 2,357 & 2,454 & 2,615 \\
\hline (st dev of log hourly wage) & 0,381 & 0,365 & 0,465 & 0,422 & 0,604 & 0,533 \\
\hline \multicolumn{7}{|l|}{ Females } \\
\hline Hours & 34,61 & 34,59 & 36,13 & 32,31 & 29,59 & 28,32 \\
\hline Log hourly wage $(€)$ & 1,974 & 2,165 & 1,918 & 2,303 & 2,114 & 2,393 \\
\hline (st dev of log hourly wage) & 0,357 & 0,362 & 0,490 & 0,445 & 0,553 & 0,514 \\
\hline
\end{tabular}

Public and private sector wages also differ in term of (both unconditional and conditional) dispersion. In particular, the standard deviation of (log) hourly wages in the public sector (private sector) is $0.533(0.604), 0.422(0.465)$ and $0.365(0.381)$ respectively in Great Britain, Italy and France. Wage dispersion appears to be wider in Great Britain, as opposed to Italy and France, especially in the private sector. To inspect the distribution of wages across sectors, we used non-parametric methods (kernel density estimator) to fit the density of hourly wages, which we then plot in Figure 2 (a-c) for each country. Estimated densities confirm that (hourly) wages in public sector, in all countries, have both a higher mean and a lower dispersion with respect to the private sector. 
Figure 2 - Distribution of hourly wages in the public and private sector

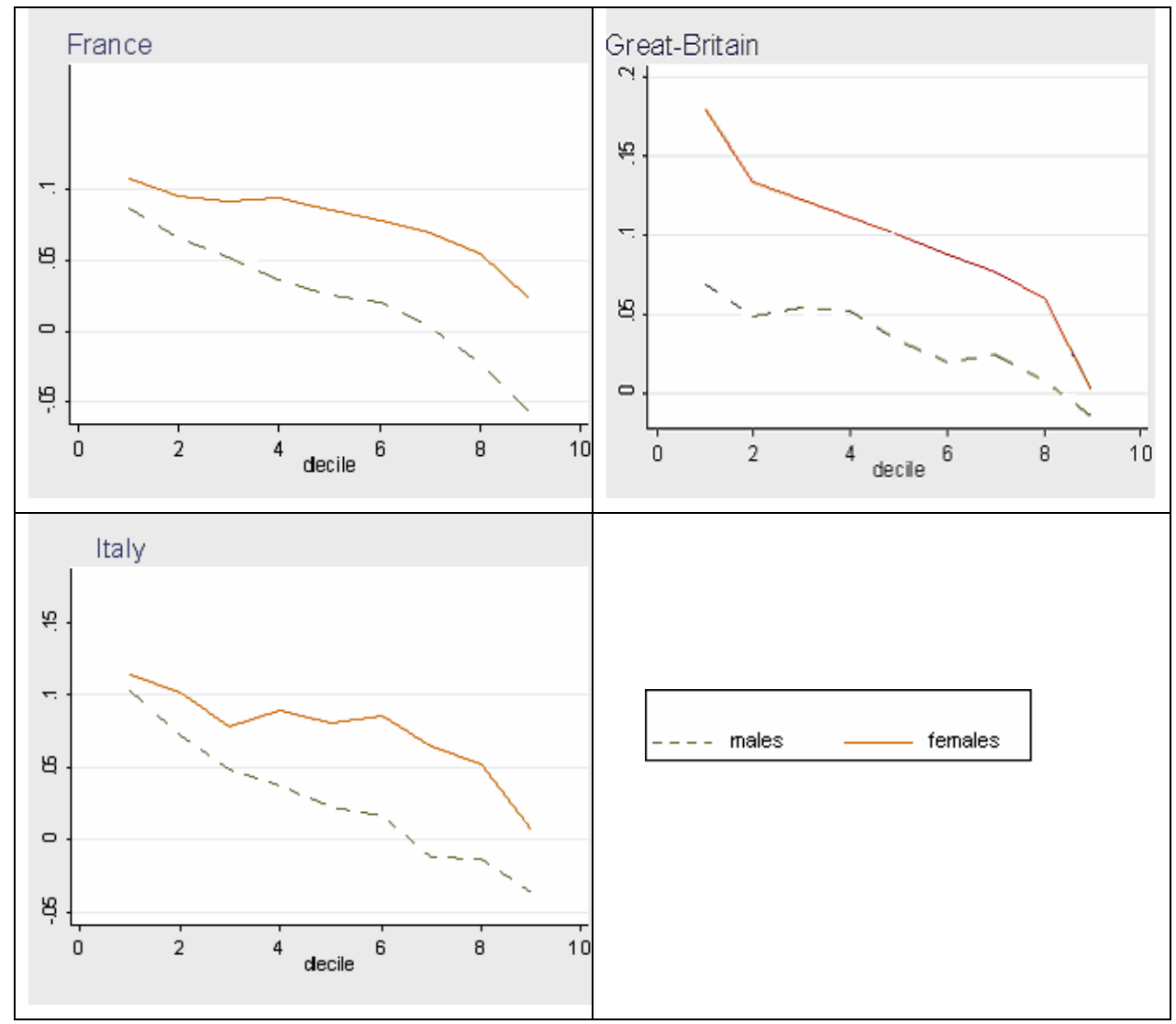

\section{Public private wage differentials: a Cross-country Comparison}

When we estimate the public-private sector pay gap using OLS techniques, pooling data for both sectors and introducing a dummy variable for the public sector, we find a positive, statistically significant, coefficient in all countries. In general, as shown in table 2 (column 1), conditioning on a larger set of variables reduces the estimated gap as well as differences across countries. When the sample is split by gender, females show a much larger public sector wage gap as opposed to males. The above evidence based on a naïve estimation technique, however, suffers from several limitations ${ }^{6}$. In particular, given the differences in the distribution of pay between the sectors (i.e. public sector low-skilled workers, located in

6 The whole set of estimations is contained in an Appendix which is not reported but can be obtained upon request from the authors. 
the lower part of the distribution, enjoy higher pay as compared to private sector workers), OLS methods based on conditional mean wage may result overly restrictive. In this context, the use of quantile regression methods (QRM), which allow the analysis of the entire wage distribution, may be preferable: for the (marginal) effect of the covariates on the dependent variable can differ at different points of the wage distribution. These outcomes may also be interpreted as the effect of a different distribution of unobserved determinants of wages, for a given set of workers characteristics, at various points of the wage distribution. The analytical framework we adopt for the estimation is based on the quantilic regression methodology developed by Koenker and Basset (1978) and applied, in the context of wage equations, by Chamberlain (1994), Poterba and Rueben (1994), Buchinsky (1994, 1996, 1997) and Machado and Mata (1999).

Assume that the quantile $q^{\text {th }}$ of the conditional distribution of wages is a linear function of worker's characteristics $\left(X_{k}\right)$.

$$
Q^{q}\left(y_{k} / X_{k}\right)=X_{k} \beta_{k}^{q}+P U B_{k} * \delta^{q}
$$

Koeker e Basset (1978) have shown that quantiles can be estimates by minimising $\left(\beta^{q}, \delta^{q}\right)$ in [2]

$\underset{\beta^{q} \sigma_{k}<0}{\min } \sum^{*}\left|y_{k}-X_{k} \beta^{q}-P U B_{k} * \delta q\right|+\sum_{\sigma_{k}>0}(1-q) *\left|y_{k}-X_{k} \beta^{q}-P U B_{k} * \delta^{q}\right|$

In the empirical analysis that follows, we first estimates the impact of workers' characteristics and job attributes on public and private sectors wages, respectively for males and females, and next we proceed decomposing the wage differential into a component that is due to differences in observed characteristics and a component that is due to differences in the rewards.

\subsection{Main Results}

To examine the effects of differences in characteristics on the public sector pay gap at different points in the distribution, we first carry out a series of quantile regressions on the pooled data set and compare the main set of results with OLS estimates. Pooled regressions impose the restriction that the returns to observed characteristics are the same for the two sectors and that public-private differences only depend on a shift factor (i.e. as shown in equation [2]). Hence, the estimated public sector dummy captures the extent to which the public sector pay gap remains unexplained -- at the various quantiles -- after controlling for individual characteristics, gender and job attributes. Table 2 presents estimates of the public- 
private sector wage differential at every decile of the wage distribution, using two different specifications: first, controlling for standard human capital variables only and then adding job characteristics and regional controls (capital city).

Table 2. Estimates of Public Sector Pay Gap.

\begin{tabular}{|c|c|c|c|c|c|c|c|c|c|c|}
\hline & \multirow[t]{2}{*}{ OLS } & \multicolumn{9}{|c|}{ Deciles } \\
\hline & & 0.1 & 0.2 & 0.3 & 0.4 & 0.5 & 0.6 & 0.7 & 0.8 & 0.9 \\
\hline \multicolumn{11}{|l|}{$\overline{\text { France }}$} \\
\hline Model 1 & 0,070 & 0,094 & 0,110 & 0,106 & 0,096 & 0,082 & 0,069 & 0,053 & 0,033 & 0,003 \\
\hline$(n=49286)$ & $(20,03)$ & $(19,23)$ & $(26,95)$ & $(22,98)$ & $(25,92)$ & $(20,83)$ & $(16,05)$ & $(12,00)$ & $(6,55)$ & $(0,41)$ \\
\hline Model 2 & 0,055 & 0,095 & 0,084 & 0,072 & 0,070 & 0,064 & 0,054 & 0,041 & 0,026 & $-0,006$ \\
\hline$(n=49286)$ & $(17,67)$ & $(23,02)$ & $(24,04)$ & $(22,49)$ & $(21,24)$ & $(17,93)$ & $(15,58)$ & $(11,16)$ & $(6,08)$ & $(1,00)$ \\
\hline \multicolumn{11}{|l|}{ Italy } \\
\hline Model 1 & 0,113 & 0,172 & 0,150 & 0,130 & 0,122 & 0,117 & 0,109 & 0,111 & 0,107 & 0,059 \\
\hline$(\mathrm{n}=4820)$ & $(8,50)$ & $(7,64)$ & $(8,49)$ & $(9,44)$ & $(9,42)$ & $(9,22)$ & $(7,26)$ & $(7,12)$ & $(6,34)$ & $(2,22)$ \\
\hline Model 2 & 0,049 & 0,114 & 0,084 & 0,069 & 0,060 & 0,061 & 0,053 & 0,038 & 0,027 & $-0,017$ \\
\hline$(\mathrm{n}=4820)$ & $(3,67)$ & $(4,46)$ & $(4,95)$ & $(4,30)$ & $(4,60)$ & $(5,34)$ & $(4,17)$ & $(2,51)$ & $(2,45)$ & $(0,83)$ \\
\hline \multicolumn{11}{|l|}{ Great Britain } \\
\hline Model 1 & 0,079 & 0,154 & 0,134 & 0,130 & 0,114 & 0,099 & 0,075 & 0,052 & 0,034 & $-0,025$ \\
\hline$(n=16864)$ & $(9,14)$ & $(13,26)$ & $(12,31)$ & $(13,45)$ & $(11,30)$ & $(10,79)$ & $(7,56)$ & $(4,95)$ & $(2,78)$ & $(1,75)$ \\
\hline Model 2 & 0,064 & 0,137 & 0,103 & 0,089 & 0,082 & 0,073 & 0,061 & 0,053 & 0,040 & $-0,005$ \\
\hline$(n=16864)$ & $(8,07)$ & $(10,55)$ & $(10,54)$ & $(10,47)$ & $(10,37)$ & $(8,61)$ & $(7,33)$ & $(5,84)$ & $(3,48)$ & $(0,37)$ \\
\hline
\end{tabular}

Note : Dependent variable : log of hourly wage. T-values in parentheses. Model 1 basic capital human characteristics : female, marital status, education in years, age, age squared. Model 2 same variables as Model 1 plus occupations (managers, intermediate, clerks, workers), part-time jobs and regions (region where capital city is placed).

The main set of results from quantile regressions show that the public sector pay gap declines along the wage distribution in all countries ${ }^{7}$. The other variables included (though not reported in the table) are in line with the standard findings in the literature: returns to education and age increase over the deciles in all countries ${ }^{8}$. These findings confirm our previous claim that focussing on the average public sector gap might be not appropriate. Since much of the empirical evidence we reviewed suggests the existence of a different gap across genders, in figures 3(a-c) we report coefficient estimates of the public sector dummy, by deciles, in separate wage regressions for males and females. As it can be seen from the

${ }^{7}$ We tested the equality of coefficients by carring out an F-test for equality of the public sector dummies. The hypothesis of equality is rejected at the 1 percent significance level. 
figures, the public sector gap is decreasing along the wage distribution in all countries, and it is much higher for female workers as compared to their male conterpart. In the case of females the gap remains positive even at the top deciles, while for males in the upper part of the distribution it turns negative. It is worth noting that in the case of Britain, the difference in the public sector wage gap across gender is far higher at the lowest deciles and decreased thereafter, conversely in Italy and France differences in the gap, across genders, increases along the distribution and it is highest at the top deciles. In other words, if we had to interpret these patterns in terms of male to female wage differences, the evidence seems to suggest that female are relatively (much) better off being in the public sector - with respect to men -- at the lowest deciles in Great Britain, whilst the opposite is true (i.e. they are relatively better off at the highest deciles) in France and Italy. Whilst 'glass ceiling effect' can be the explanation in the case of France and Italy case, low pay for low skilled women in the private sector may account for the British evidence.

\footnotetext{
${ }^{8}$ The only exception is Italy where returns to age decrease monotonically over the distribution.
} 


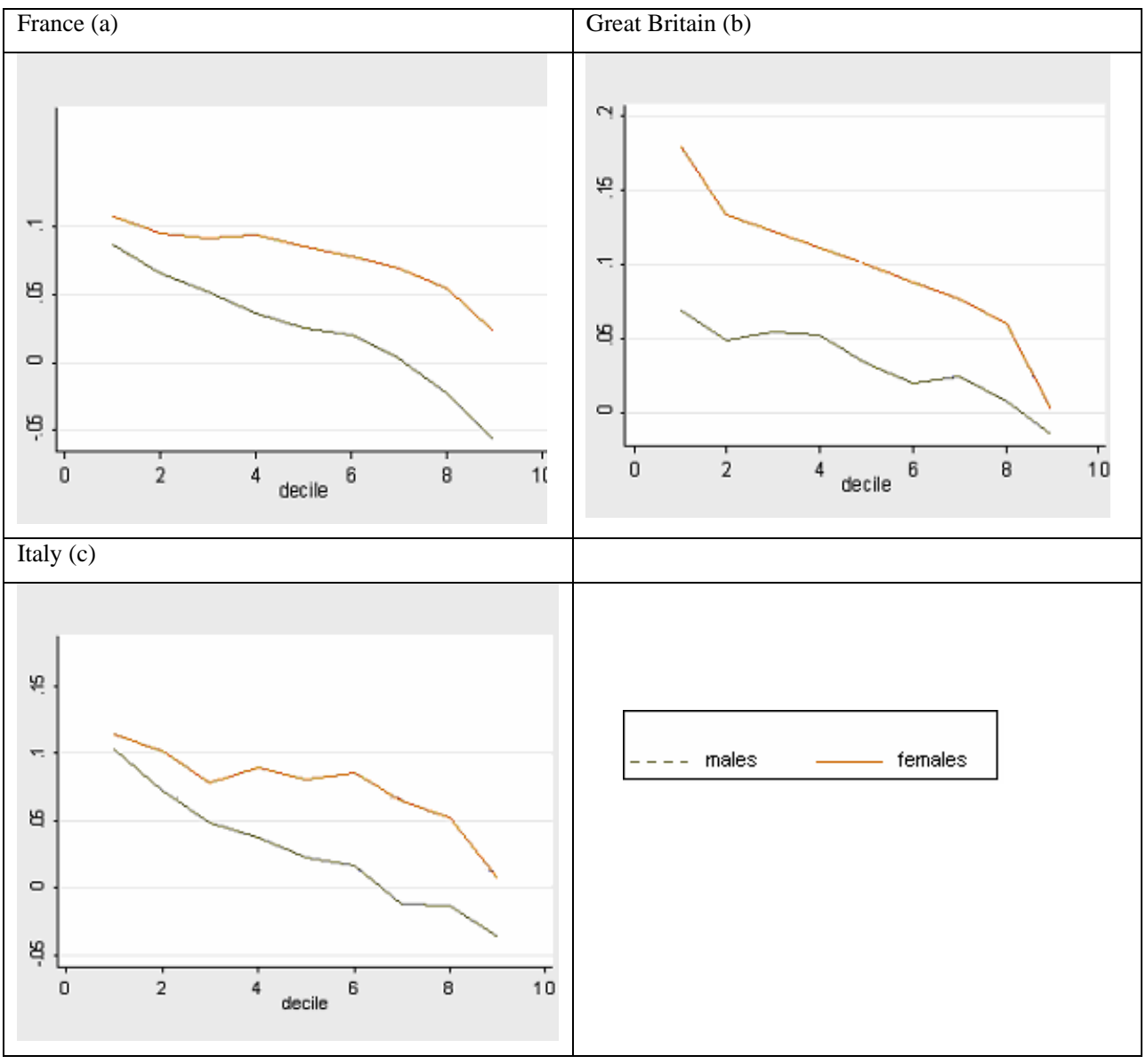

As previously discussed, pooled regressions fail to capture differences in productivity related characteristics by sectors; hence we estimated more flexible specifications by fitting separate earnings equations for the public and the private sector and, within each sector, by gender. In general, results from separate public and private sector equations -- as well as by gender - confirm the findings that parameter estimates are not stable along the wage distribution. However, while returns to characteristics tend to decline over the wage distribution in Italy and France, in Great Britain the opposite pattern is observed. This is hardly surprising given the institutional differences discussed in the previous sections, with collective bargaining and union presence imposing lower returns to enforce a more egalitarian wage structure in Italy and France, and the prevalence of employer discretion in wage setting to attract and motivate workers in Great Britain. However, since we are primarily interested in the public sector pay gap, we do not report the detailed results and return the analysis of the differential to section 5 , where we decompose the public sector wage gap into that part 
explained by differences in observed characteristics and that part due to differences in rewards.

\section{Decomposing the Gap and Explaining the Differences}

In this section, we present a decomposition of the wage differentials applied to both OLS and QRM estimates. The standard methodology for analysing public-private sector wage differentials, with OLS, is to decompose the observed gap into two components: (i) a difference in average worker characteristics and job attributes between sectors; and (ii) a difference in the returns to worker characteristics and job attributes between sectors and an interaction effect treated as a residual component (Blinder, 1973; Oaxaca, 1973; Oaxaca and Ransom, 1994) all computed at the mean of the wage distribution ${ }^{9}$. The evidence presented in previous sections, however, suggests that the public-private wage gap may be higher in the lower part of the wage distribution. To explore further this hypothesis we decompose wage differences, quantile by quantile, using an Oaxaca-Ransom type decomposition ${ }^{10}$. However, one main difference between OLS and QRM is that, whilst OLS estimators ensure that the 'predicted wage' evaluated at the sample average vector of characteristics is equal to the sample average wage, QRM estimators do not share the same property. We follow a simple version of the approach developed by Machado and Mata (2000) which is based on quantile regression techniques and extend it to account for the "index" problem as suggested in Neumark (1988) and Oaxaca and Ransom (1988 and 1994). The procedure is to generate counterfactual densities at each quantile of the distribution. In practice, as described in [4], we compare public and private workers characteristics (personal and job attributes) evaluated at the remuneration $\left(\beta^{*}(q)\right)$ that an individual at random would get in the whole economy (first part of equation [4]); and the density that would be observed if private and public sector workers, respectively, maintained their own individual and job characteristics but were going to be paid like an individual chosen at random in the economy (second part of equation [4], in square brackets $)^{11}$. In so doing, however, the difference between two quantiles of the marginal wage densities between the public and the private sector weighted by the

\footnotetext{
${ }^{9}$ In the literature the wage differential due to different returns is often referred to as the 'unexplained' part, and given a residual interpretation (i.e. with respect to what is explained by different characteristics), however, it is not clear if the decomposition will over or under estimate the residual. This should depend on whether omitted variables are positively or negatively correlated with productivity and on the distribution of the omitted variables across both sectors.

10 Different techniques have been proposed in the literature for analysing differences in distributions, examples are: Dinardo, Fortin, and Lemieux (1996); Donald, Green, and Paarsch (2000); Fortin and Lemieux (1998) and Machado and Mata (2000).

11 A similar approach has also been used by Mueller (1998) and Albrecht et al. (2003).
} 
characteristics of workers does contain an additional component, which we consider of second order of magnitude and treat as a residual.

$$
y^{P B}(q)-y^{P R}(q)=\left(X^{P B}-X^{P R}\right) \beta^{*}(q)+\left[X^{P B}\left(\beta^{P B}(q)-\beta^{*}(q)\right)+X^{P R}\left(\left(\beta^{*}(q)-\beta^{P R}(q)\right)\right] \quad\right. \text { [4] }
$$

In table 3 we report the results of the decomposition and compare both standard methods and QRM type methods.

Table 3. Decomposition of public/private sector earnings differentials

\begin{tabular}{|c|c|c|c|c|c|c|c|c|c|c|}
\hline France & OLS & 0.1 & 0.2 & 0.3 & 0.4 & 0.5 & 0.6 & 0.7 & 0.8 & 0.9 \\
\hline \multicolumn{11}{|l|}{$\overline{\text { Males }}$} \\
\hline Raw differential (log) & 0,116 & 0,148 & 0,141 & 0,132 & 0,126 & 0,124 & 0,120 & 0,115 & 0,099 & 0,072 \\
\hline Differences in return & 0,016 & 0,086 & 0,063 & 0,045 & 0,032 & 0,024 & 0,015 & 0,005 & $-0,017$ & $-0,055$ \\
\hline \multicolumn{11}{|l|}{ Females } \\
\hline Raw differential (log) & 0,191 & 0,183 & 0,188 & 0,198 & 0,206 & 0,205 & 0,204 & 0,196 & 0,183 & 0,168 \\
\hline Differences in return & 0,072 & 0,107 & 0,093 & 0,093 & 0,093 & 0,084 & 0,078 & 0,069 & 0,054 & 0,034 \\
\hline Italy & OLS & $\mathbf{0 , 1}$ & 0,2 & $\mathbf{0 , 3}$ & 0,4 & 0,5 & 0,6 & 0,7 & 0,8 & $\mathbf{0 , 9}$ \\
\hline \multicolumn{11}{|l|}{$\overline{\text { Males }}$} \\
\hline Raw differential (log) & 0,285 & 0,346 & 0,283 & 0,261 & 0,261 & 0,265 & 0,267 & 0,265 & 0,280 & 0,281 \\
\hline Differences in return & 0,009 & 0,081 & 0,050 & 0,034 & 0,033 & 0,021 & 0,017 & $-0,002$ & $-0,005$ & $-0,019$ \\
\hline \multicolumn{11}{|l|}{ Females } \\
\hline Raw differential (log) & 0,385 & 0,480 & 0,413 & 0,380 & 0,378 & 0,377 & 0,394 & 0,396 & 0,398 & 0,363 \\
\hline Differences in return & 0,042 & 0,080 & 0,066 & 0,047 & 0,054 & 0,052 & 0,046 & 0,040 & 0,038 & 0,013 \\
\hline Great-Britain & OLS & 0,1 & 0,2 & $\mathbf{0 , 3}$ & 0,4 & 0,5 & 0,6 & 0,7 & $\mathbf{0 , 8}$ & $\mathbf{0 , 9}$ \\
\hline \multicolumn{11}{|l|}{ Males } \\
\hline Raw differential (log) & 0,161 & 0,190 & 0,178 & 0,182 & 0,189 & 0,169 & 0,174 & 0,153 & 0,147 & 0,110 \\
\hline Differences in return & 0,023 & 0,058 & 0,046 & 0,046 & 0,051 & 0,034 & 0,042 & 0,020 & 0,006 & $-0,033$ \\
\hline \multicolumn{11}{|l|}{ Females } \\
\hline Raw differential (log) & 0,278 & 0,338 & 0,304 & 0,297 & 0,286 & 0,285 & 0,272 & 0,272 & 0,259 & 0,203 \\
\hline Differences in return & 0,083 & 0,163 & 0,120 & 0,105 & 0,089 & 0,083 & 0,070 & 0,067 & 0,056 & 0,002 \\
\hline
\end{tabular}

Results of the decomposition analysis clearly show that, in all countries and for both genders, the portion of the public sector wage gap accounted by differences in returns to (observed) characteristics declines monotonically from lower to upper deciles. In other words, differences in returns can explain a significant portion of the differential in the lower part of the wage distribution, while this vanishes in the upper part (i.e. in some cases it is negative). For males the estimated wage gap due to differences in returns becomes negative at top deciles, implying that there are significant differences in individual (observed) characteristics and occupations across sectors. For females, differences in returns are particularly important 
at the bottom of the wage distribution while they become insignificant (though still positive) at the top deciles.

However, when comparing the public sector wage gap by deciles across gender, substantial differences emerge in the countries considered. Italy, for example, shows the highest public sector raw differential at each quantile for both males and females but differences in the estimated wage gap due to returns are much smaller if compared to the other countries. Great Britain, in particular, exhibits a significantly higher estimated difference in returns for females at the lower deciles, while France is in between. In general males have much smaller public sector wage gap particularly in the upper part of the distribution where they turn negative.

\section{Concluding Remarks}

In this paper we have investigated public-private pay determination - using French, British and Italian micro data. Using quantile regression methods, we show that the publicprivate (hourly) wage differential is sensitive to the choice of quantile - thus rejecting the hypothesis of a constant wage differential (as implied in OLS methods) - and that the pattern of premia varies with both gender and skill. In France, Great-Britain and Italy low skilled public sector workers are paid higher wages with respect to their private sector counterparts, whilst the reverse is true for high skilled workers. These effects are more pronounced for females. In general wage gap estimates suggest that female are better off being in the public sector, particularly at the lowest deciles, whilst the opposite is true for men at the highest deciles. Institutional differences across countries seem to indicate that a 'glass ceiling effect' characterises private sector pay (at top deciles) for females in France and Italy, while a "low floor effects" is what distinguishes private sector pay of low skilled women in Britain.

Different economic implications are in order. On the one hand, empirical evidence confirms that the public sector is a "fair employer", both reducing pay differences by gender and compressing pay dispersion with respect to the private sector. On the other hand, the existence of a positive public-private pay differential, along most of the wage distribution, also means that the public sector pays more than the opportunity wage low skilled labour, while less than what is needed to attract, retain and motivate high skilled workers. 


\section{References}

Albrecht, J., Bjorklund, A. and Vroman, S. (2003) "Is There a Glass Ceiling in Sweden?", Journal of Labor Economics, 21, 145-177.

Bardasi, E., (1996), "I differenziali salariali tra pubblico e privato. Un'analisi microeconometrica", Lavoro e relazioni industriali, 3, 24-57.

Bazen, S., Gregory, M. and Salverda W. (Eds), (1998) Low-Wage Employment in Europe, Edward Elgar, Cheltenham.

Bender, K.A., and Elliott. F., (1999), "Relative Reanings in the UK Public Sector: The Impact of Pay reform on Pay Structure, in Elliott, B., Lucifora, C. and Meurs, D. (eds.) Public Sector Pay Determination in the European Union, Macmillan, 285-328.

Blackaby, D. H., PD Murphy and NC O'Leary (1999) "The Payment of Public Sector Workers in the UK: Reconciliation with North-American Findings", Economics Letters, vol. $65,239-243$.

Blinder, A. S. (1973) "Wage Discrimination: Reduced Form and Structural Estimates", Journal of Human Resources, 8, 436-455.

Brunello, G. and Dustmann C. (1997) "Le retribuzioni nel settore pubblico e privato in Italia e in Germania: un paragone basato su dati microeconomici" in Dell'Aringa, C. (ed.) Rapporto ARAN sulle retribuzioni, 1996, Collana ARAN, Roma: Franco Angeli Editore.

Buchinsky, M. (1994). "Changes in the U.S. Wage Structure 1963-1987: Application of Quantile Regression”. Econometrica, 62. 405-458.

Buchinsky, M. (1996). "Women's Return to Education in the US. Exploration by Quantile Regression with Non-Parametric Sample Selection Correction". Department of EconomicsBrown University.

Buchinsky, M. (1997). "Recent Advances in Quantile Regression Models: A Practical Guideline for Empirical Research", Journal of Human Resources, 32, 234-253

Cannari, L., Pellegrini, G. and Sestito, P. (1989) "Redditi da lavoro indipendente: un' analisi in termini di capitale umano", Temi di discussione, Banca d'Italia, N.124.

Chamberlain, G. (1994). "Quantile Regression, Censoring and the Structure of Wages" in C.A. Sims, (eds.) Advances in Econometrics 6th World Congress. Vol 1. Cambridge

Comi, S., Ghinetti P., Lucifora C. (2002), "La distribuzione dei salari nel settore pubblico e nel settore privato: un'analisi disaggregata", in Dell'Aringa, C. e C.Lucifora (eds.), Dinamica occupazionale e salariale, Vita e Pensiero.

Dell’Aringa C., Della Rocca G. (1999), Razionalizzazione e Relazioni Industriali nella Pubblica Amministrazione in Europa, Quaderni ARAN, Milano, F. Angeli, 1999.

Di Nardo, J. Fortin, N. and Lemieux, T. (1996). "Labor Market Institutions and the Distribution of Wages, 1973-1992: A Semiparametric Approach". Econometrica, 64, 10011044. 
Disney R and Gosling A., (1998), "Does it pay to work in the public sector?", Fiscal Studies $19,347-374$.

Disney R and Gosling A., (2003), “A New Method for Estimating Public Sector Pay Premia: Evidence from Britain in the 1990s", CEPR, DP. 3787.

Donald, S. G., Green D A, and Paarsch H. J. (2000), “'Differences in Wage Distributions between Canada and the United States: An Application of a Flexible Estimator of Distribution Functions in the Presence of Covariates," Review of Economic Studies, 67, 609-633.

Elliott, R.F., and Duffus, K, (1996), "What Has Been Happening to Pay in the Public Service Sector of the British Economy. Developments over the Period 1970-1992", British Journal of Industrial Relations, 34 (1), 110-123.

Elliott, B., Lucifora, C. and Meurs, D. (eds.) Public Sector Pay Determination in the European Union, MacMillan, 138-191.

European Parliament (1998), "From the Ecu to the Euro", Doc.166.626/rev2, 1998.

Fortin, N. and T. Lemieux (1998). "Rank Regressions, Wage Distributions, and the Gender Gap". Journal of Human Resources, 33, 610-643.

Fournier J.Y (2001), Comparaison des salaires des secteurs public et privé, INSEE document de travail, G 2001/11, 3-29.

Girard J-P. \& Lheritier J-L. (1992), “Les salaries en 1990”, INSEE Résultats n¹92, EmploiRevenu $\mathrm{n}^{\circ} 34$.

Godderis J.H. (1988), “Compensating Differentials and Self-Selection : an Application to Lawyers”, Journal of Political Economy, 96(2), 411-428.

Gregory R. and Borland J., (1999). Recent developments in public sector labor markets in Ashenfelter, O. and Card D. (eds.), Handbook of Labor Economics, North Holland, vol 3C. 3573-3630

Guillotin Y., and Meurs D. (1999), "Wage Heterogeneity in the French Public Sector: Some First Insights", in Elliott, B., Lucifora, C. and Meurs, D. (eds.) Public Sector Pay Determination in the European Union, MacMillan, 70-112.

Hamermesh, Daniel S \& Wolfe, John R, (1990). "Compensating Wage Differentials and the Duration of Wage Loss" Journal of Labor Economics, 8 (1), S175-97

Hartog, J. and Osterbeek, H. (1993) "Public and Private Sector Wages in the Netherlands", European Economic Review, 37, 231-251.

INSEE (1996), "L’évolution des salaires”, Synthèses, 4 (March)

Katz L. and Krueger A. (1991) "Changes in the Structure of Wages in the Public and Private Sector", Research in Labour Economics, JAI Press, 12.

Koenker, R. and G. Bassett (1978). "Regression Quantiles". Econometrica, 46, 33-50.

Lucifora C. (1999), Rules vs Bargaining : Pay Determination in the Italian Publi Sector, in 
Lucifora C. (2000), "Inequality, Low Wage Employment and Labour Market Institutions", in Bazen, S., Gregory, M. and Salverda W. (eds.) Pay Inequality in Europe, Oxford University Press, Oxford, 12-25.

Machado, J.A.F. and Mata, J. (2000). "Sources of Increased Wage Inequality”. Mimeo.

Manski, C.F. (1993), The Selection Problem in Econometrics and Statistics. In Maddala, G.S., Rao, C.R. \& Vinod, D.H. (eds.): Handbook of Statistics, Volume 11. Amsterdam: Elsevier.

Manski, C.F. (1995), Identification Problems in the Social Sciences, Harvard University Press.

Melly B., (2002), "Public-private sector wage differentials in Germany: evidence from quantile regression", mimeo, University of St Gallen.

Mueller, R. (1998), "Public-Private Sector Wage Differentials in Canada: Evidence from Quantile Regression". Economics Letters, 60, 229-235.

Nawata (1996), "Estimation of sample seclection models", Econometric Review, 15 (4), 387 400.

Neumark, D. (1988). "Employers Discriminatory Behaviour and the Estimation of Wage Discrimination". Journal of Human Resources, 23, 279-295.

Oaxaca, R.L. (1973), "Male-Female Wage Differentials in Urban Labour Markets", International Economic, Review, 14 (3), 693-709.

Oaxaca R L. and Ransom M. R. (1988), Searching for the effect of unionism on wages of union and non-union workers, Journal of Labor Research, 9, 139-148

Oaxaca, R.L. and Ransom M.R. (1994), "On discrimination and the decomposition of wage differentials", Journal of Econometrics,61, 5-21.

OECD, (1996), Trends in Public Sector Pay in OECD Countries, PUMA, Paris.

OECD, (2000), Trends in Public Sector Pay in OECD Countries, PUMA, Paris.

Poterba, J. and K. Rueben (1994). "The Distribution of Public Sector Wage Premia: Evidence Using Quantile regression Methods". National Bureau of Economic Research W.P. 4734.

Rees, H. and Shah, A. (1995) "Public-Private sector wage differentials in the UK", The Manchester School, LXIII, 52-68.

Sandy R., Elliott R.F. (1996), Unions and Risk: Their Impact on the Level of Compensation for Fatal Risk, Economica, 63, 291-309. 